DOI: $\underline{\text { http://doi.org/10.21698/simi.2018.fp55 }}$

\title{
VERIFYING THE HEIGHT OF THE DISCHARGE CHIMNEY FOR EMISSIONS RESULTING FROM HAZARDOUS WASTE INCINERATION INSTALLATIONS
}

Loredana Irena Negoita, Maria Popa

Petroleum - Gas University of Ploiesti, 39 Bucuresti, 100680, Ploiesti, irena.negoita@gmail.com, Romania

\begin{abstract}
The paper compares the results obtained by applying three calculation methodologies for the height of the chimney of a hazardous waste installation. Thermal waste treatment processes are a feasible option after recovery (collection, sorting, recycling) and prior to controlled disposal.

Monitoring data at a hazardous waste incineration plant made it possible to calculate three heights of the incinerator emission network.

The incineration plant is thus operated in such a way that the emissions of the harmful substances of the chimney are in conformity with the VLE values transposed into the national legislation by Law no. 278/2013 regarding industrial emissions, Annex 6.

Three methodologies are used to determine the height of the chimney: according to the Technical Instructions for Air Quality Control - "TA Luft", according to "Arrêté du 25/01/91 relatif aux incinération de résidus urbains" and according to "RS 814.318." 142.1 Ordonnance sur la l'air (Opair) ".
\end{abstract}

Keywords: chimney, incineration, monitoring, waste treatment

\section{Introduction}

In the integrated waste management system, the incineration of hazardous waste is considered together with their controlled storage and their chemical, physical and biological treatment as a method of disposal of combustible wastes which are no longer proprietary for material recovery and which due to their types, and quantities are particularly dangerous to population health and environmental factors, are explosive or flammable, contain or can generate pathogenic germs of transmissible diseases. These are predominantly waste types that contain large amounts of organic compounds or have a high potential for risk. (Lazaroiu 2005)

Incineration consists in the disposal of waste by burning it in an incineration plant at a temperature of more than $850^{\circ} \mathrm{C}$.

The incineration plant may be a fixed or mobile technical plant and equipment for the thermal treatment of waste, with or without the recovery of the resulting combustion heat (http://eippcb.jrc.ec.europa.eu/reference/BREF/wt bref 0806.pdf ).

A waste incineration plant consists of the following operating areas:

- Takeover of waste;

- Temporary storage, pre-treatment (if necessary);

- Supply to the incineration plant;

- Removal and treatment of residual ash; 


\section{INTERNATIONAL SYMPOSIUM "THE ENVIRONMENT AND THE INDUSTRY", SIMI 2018, PROCEEDINGS BOOK}

- Treatment and recovery of emissions

\section{Materials and methods}

Monitoring data at a hazardous waste incineration plant made it possible to calculate three heights of the incinerator emission network.

The incineration plant of BIC systems has a total incineration capacity of 23000 tonnes/year and $2880 \mathrm{~kg} /$ hour and consists of: a rotary kiln (primary combustion chamber), a combustion chamber (secondary combustion chamber) with 2 burners + 1 (for each room), fuelled with conventional fuel (LPG), connected to an air pollution control system, all controlled and monitored (http://wwwold.anpm.ro/upload/39867_Acord\%20de\%20mediu\%20SC\%20PRO\%20AIR\%20C

\section{LEAN.pdf).}

This type of incinerator is equipped with an analyser that continuously monitors (record and print) independently the following parameters: temperature, oxygen, $\mathrm{CO}, \mathrm{NO}, \mathrm{NO}_{2}, \mathrm{SO}_{2}, \mathrm{HC}$ measurement module (uncharged hydrocarbons).

Total organic carbon (TOC) and total dust are controlled by continuous monitoring of combustion temperature, excess oxygen and uncharged hydrocarbons (HC).

The pollutants that could be emitted into the atmosphere and must be monitored in accordance with the Law no. 278/2013 regarding industrial emissions, Annex 6 for incineration activity are: dust, TOC, $\mathrm{HCl}, \mathrm{HF}, \mathrm{SO}_{2}, \mathrm{NO}_{\mathrm{x}}$, heavy metals (Cd, Tl, Hg, $\mathrm{Sb}, \mathrm{As}, \mathrm{Pb}, \mathrm{Cr}, \mathrm{Co}, \mathrm{Cu}, \mathrm{Mn}, \mathrm{Ni}, \mathrm{V}$ ) dioxins and furans (Law no. 278/2013).

The determinations are made during the incineration step (Lazaroiu 2006, Serbanescu et al 2017).

The incineration plant is thus operated in such a way that the emissions of the harmful substances of the chimney are in conformity with the VLE values transposed into the national legislation by Law no. 278/2013 regarding industrial emissions, Annex 6. With the monitored data, is checked the actual emission chimney height. Three methodologies are used to determine the height of the chimney: according to the Technical Instructions for Air Quality Control - "TA Luft", according to "Arrêté du 25/01/91 relatif aux incinération de résidus urbains" and according to "RS 814.318." 142.1 Ordonnance sur la l'air (Opair)"(Arrêté de 25/01/91, R.S. 814.318.142.1, Ordonnance sur la protection de l'air, Neue TA-LUFT 2002).

\section{Results and Discussions}

Calculation the height of the chimney incinerator according to the Technical Instructions for Air Quality Control - "TA Luft" (Neue TA-LUFT 2002)

The study was carried out on a hazardous waste incineration plant, $600 \mathrm{KW}$ thermal power, with a dry purification plant for waste gases discharged through the chimney. The installation is characterized by: thermal power $600 \mathrm{MW}$, low caloric power $\mathrm{H}_{\mathrm{u}}$ : $16 \mathrm{MJ} / \mathrm{kg}$, oxygen reference value: $11 \%$; inner diameter of the chimney at the outlet (d): $1.20 \mathrm{~m}$; flue gases temperature (t): $80^{\circ} \mathrm{C}$; Incinerator chimney height: 30 m.

Limit values to be met according to Law no. 278/2013 regarding industrial emissions for the indicators of interest and in this paper are presented in Table 1. 


\section{INTERNATIONAL SYMPOSIUM "THE ENVIRONMENT AND THE INDUSTRY", SIMI 2018, PROCEEDINGS BOOK}

Table 1. Emission limit values (VLE), daily averages for waste incineration plants $\mathrm{mg} / \mathrm{Nm}^{3}$ with $11 \% \mathrm{O}_{2}$.

\begin{tabular}{ccc}
\hline Polutant & $\begin{array}{c}\text { VLE, } \mathrm{mg} / \mathrm{Nm}^{3} \\
\text { with } 11 \% \mathrm{O}_{2}\end{array}$ & $\begin{array}{c}\text { The confidence intervals values of 95\% for } \\
\text { the measurement techniques, \% }\end{array}$ \\
\hline dust & 10 & 30 \\
\hline $\mathrm{SO}_{2}$ & 50 & 20 \\
\hline $\mathrm{NO}_{\mathrm{X}}$, like $\mathrm{NO}_{2}{ }^{*}$ & 400 & 20 \\
\hline
\end{tabular}

* for capacity installation less than $6 \mathrm{t} / \mathrm{h}$

In order to cover the chimney height, the calculations will be carried out using the value of the upper limit corresponding to the confidence interval for VLE (13 $\mathrm{mg} / \mathrm{Nm}^{3}$ for dust, $60 \mathrm{mg} / \mathrm{Nm}^{3}$ for $\mathrm{SO}_{2}$ and $480 \mathrm{mg} / \mathrm{Nm}^{3}$ for $\mathrm{NO}_{x}$, like $\mathrm{NO}_{2}$ ).

Step 1: Calculation of flue gases flow, $R\left[\mathrm{~m}^{3} / \mathrm{h}\right]$, in normal conditions, $(273.15 \mathrm{~K}$, $101.3 \mathrm{kPa})$

$$
\mathrm{R}=3600 \cdot \mathrm{V} \cdot \mathrm{A}\left[\frac{\mathrm{m}^{3}}{\mathrm{~h}}\right]
$$

where: V - flue gases velocity at chimney exit (for capacity installation over $1 \mathrm{t} / \mathrm{h}$ and less with $6 \mathrm{t} / \mathrm{h}$ ): $8.0 \mathrm{~m} / \mathrm{s}<\mathrm{V}<12.0 \mathrm{~m} / \mathrm{s}$;

A - area of the chimney section at the exhaust gases outlet:

$$
\mathrm{A}=\frac{\pi \cdot \mathrm{D}^{2}}{4} \text {; }
$$

$\mathrm{A}=1.13 \mathrm{~m}^{2} ; \mathrm{R}=32572.8 \mathrm{~m}^{3} / \mathrm{h}$;

Flow rate of flue gases at $11 \%$ oxygen content is $68403 \mathrm{~m}^{3} / \mathrm{h}$.

Step 2: Calculation flow rate of emissions $(\mathrm{Q}$ in $\mathrm{kg} / \mathrm{h})$

$>Q_{\text {dust }}=68403 \mathrm{~m}^{3} / \mathrm{h} \cdot 13 \mathrm{mg} / \mathrm{m}^{3} \cdot 10^{-6}=0.89 \mathrm{~kg} / \mathrm{hQso}_{2}=68403 \mathrm{~m}^{3} / \mathrm{h} \cdot 60$ $\mathrm{mg} / \mathrm{m}^{3} \cdot 10^{-6}=4.10 \mathrm{~kg} / \mathrm{hQNO}_{2}=68403 \mathrm{~m}^{3} / \mathrm{h} \cdot 480 \mathrm{mg} / \mathrm{m}^{3}\left(\mathrm{NO}_{\mathrm{x}}\right) \cdot 10^{-6} \cdot 0,64=$ $21.01 \mathrm{~kg} / \mathrm{h}$

The conversion factor from $\mathrm{NO}_{x}$ to $\mathrm{NO}_{2}, \mathrm{f}=0.64$, is calculated as follows: in the case of combustion, the percentage of $\mathrm{NO}_{2}$ in the $\mathrm{NO}_{\mathrm{x}}$ emissions in the waste gas is approx. $10 \%$, the rest (90\%) is emitted as NO; approx. $60 \%$ of the resulting NO will be oxidized, turning to $\mathrm{NO}_{2}$.

The percentage of $\mathrm{NO}_{2}$ from the limit value of $\mathrm{C}_{\mathrm{NOx}}=400 \mathrm{mg} / \mathrm{m}^{3}$ shall be calculated as follows:

$$
\mathrm{C}_{\mathrm{NO}_{2}}=480 \mathrm{mg} / \mathrm{m}^{3 \cdot} 0.1=48 \mathrm{mg} / \mathrm{m}^{3}
$$

Percentage of $\mathrm{NO}_{2}$ by oxidation of $\mathrm{NO}$ in $\mathrm{NO}_{2}$ :

$\mathrm{NO}=\left(480 \mathrm{mg} / \mathrm{m}^{3}-48 \mathrm{mg} / \mathrm{m}^{3}\right) \cdot 0.6=259.20 \mathrm{mg} / \mathrm{m}^{3}$

Determination of the transformation factor $\mathrm{f}$, from $\mathrm{NO}_{\mathrm{x}}$, into $\mathrm{NO}_{2}$ :

$\mathrm{C}_{\mathrm{NO}_{2}}$, total $=48 \mathrm{mg} / \mathrm{m}^{3}+259.20 \mathrm{mg} / \mathrm{m}^{3}=307.2 \mathrm{mg} / \mathrm{m}^{3}$

$\mathrm{f}=307.20 \mathrm{mg} / \mathrm{m}^{3} / 480 \mathrm{mg} / \mathrm{m}^{3}=0.64$

\section{Step 3: Calculation ratio $Q / S$}

$S$ is a specific factor for pollutants used to determination the chimney height. 


\section{INTERNATIONAL SYMPOSIUM "THE ENVIRONMENT AND THE INDUSTRY", SIMI 2018, PROCEEDINGS BOOK}

Table 2. $S$ factor according Annex 7 from Technique Guide for Air (TA Luft)

\begin{tabular}{l|lllll}
\hline S factor value & $\mathrm{SO}_{\mathrm{x}}$ & $\mathrm{NO}_{2}$ & $\mathrm{HCl}$ & $\mathrm{HF}$ & $\mathrm{CO}$ \\
\hline Dust (Material particles) & 0.14 & 0.1 & 0.1 & 0.0018 & 7.5 \\
\hline 0.08 &
\end{tabular}

Q/S for dust: $0.89 \mathrm{~kg} / \mathrm{h} / 0.08=11.125 \mathrm{~kg} / \mathrm{h}$;

$\mathrm{Q} / \mathrm{S}$ for $\mathrm{SO}_{2}: 4.10 \mathrm{~kg} / \mathrm{h} / 0.14=29.29 \mathrm{~kg} / \mathrm{h}$;

$\mathrm{Q} / \mathrm{S}$ for $\mathrm{NO}_{2}: 21.01 \mathrm{~kg} / \mathrm{h} / 0.1=210.10 \mathrm{~kg} / \mathrm{h}$

Relevant is the highest coefficient $\mathrm{Q} / \mathrm{S} \Rightarrow \mathrm{Q} / \mathrm{S} \mathrm{NO}_{2}=210.10 \mathrm{~kg} / \mathrm{h}$

\section{Step 4: Height chimney of incinerator in diagram}

From nomogram, fig. 1 , for $d=1.20 \mathrm{~m}, \mathrm{t}=80^{\circ} \mathrm{C}, \mathrm{R}=68403 \mathrm{~m}^{3} / \mathrm{h}$ and $\mathrm{Q} / \mathrm{S}_{\mathrm{NO} 2}=$ $210.10 \mathrm{~kg} / \mathrm{h}$ corresponding for a chimney high, Hc, de $30 \mathrm{~m}$.

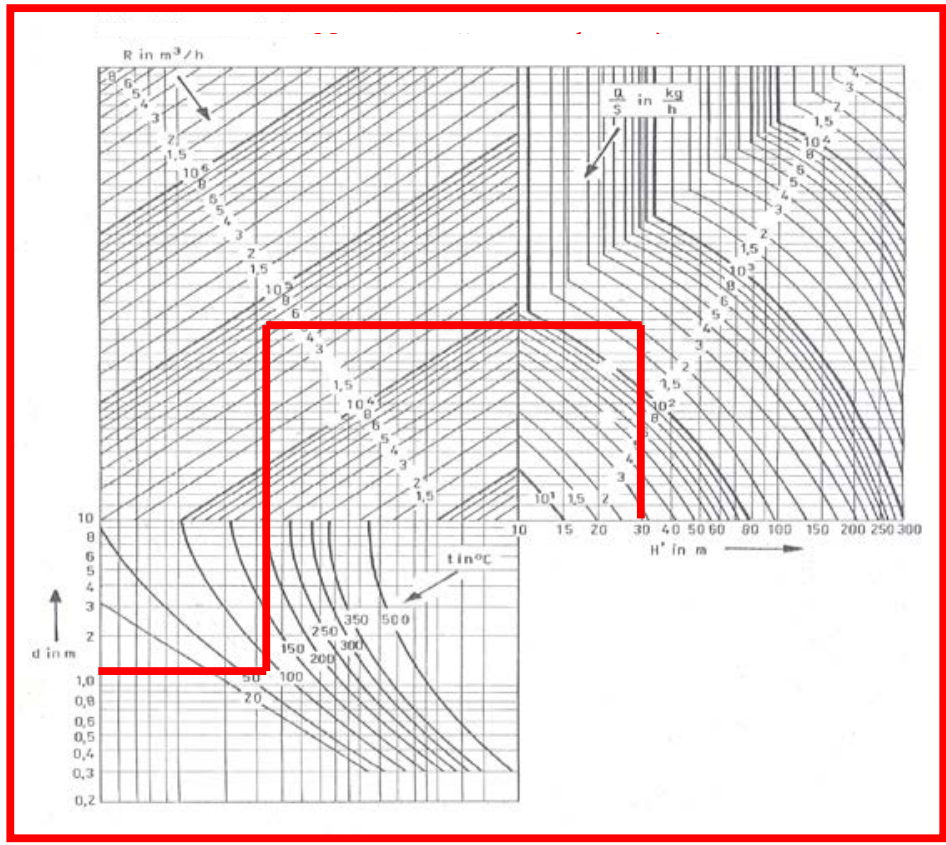

Figure 1. Nomogram for determination the chimney height of incinerator.

According to the TA Luft Technical Guide, the surface on which the assessment is made is a circle with a radius of $1.50 \mathrm{~km}$ around the chimney. In this area, existing or approved compact constructions according to the construction plan or compact vegetation have less than $5 \%$ of the area of the assessed land, which does not involve increasing the height of the chimney (Neue TA-LUFT 2002).

When determining the height of the chimney, a form of non-linear relief shall also be considered if the installation is located in a valley or the dispersion of the emissions is disturbed by an oscillation of level in the relief. If necessary, the height 


\section{INTERNATIONAL SYMPOSIUM "THE ENVIRONMENT AND THE INDUSTRY", SIMI 2018, PROCEEDINGS BOOK}

of the chimney is then increased by a correction factor. The actual height of the incinerator chimney is $30 \mathrm{~m}$.

Calculation the height of chimney incinerator according with ARRÊTÉ DU 25/01/91 RELATIF AUX INSTALLATION D' INCINÉRATION DE RÉSIDUS URBAINS (Arrêté de 25/01/91, article10).

The minimum admissible height of the chimney, respecting to the condition of the concentration of pollutants, is calculated by the relations (Lazaroiu 2005; Arrêté de 25/01/91, article10).

where:

$$
\mathrm{H}_{\mathrm{c}}=\mathrm{S}^{\frac{1}{2}} \cdot(\mathrm{R} \cdot \Delta \mathrm{T})^{-\frac{1}{6}}
$$

\footnotetext{
$>\quad \mathrm{k}=$ coefficient with 340 value for $\mathrm{SO}_{\mathrm{x}}$ and $\mathrm{NO}_{\mathrm{x}}$ (gases pollutants) and

$\mathrm{k}=680$ for dust;

$\mathrm{q}[\mathrm{kg} / \mathrm{h}]$, maximum theoretic flow rate of pollutant;

$>\quad \mathrm{C}_{\mathrm{m}}=\left[\frac{\mathrm{mg}}{\mathrm{m}_{\mathrm{N}}^{3}}\right]$, maximum admissible concentration of pollutant to the soil level;
}

$>\mathrm{Cr}_{\mathrm{r}}$ - reference concentration, 0,15 value to ash and $\mathrm{SO}_{2}$, and 0,14 value to $\mathrm{NO}_{\mathrm{x}}$ (Arrêté de 25/01/91)

$>\mathrm{C}_{0}-$ annual average to concentration at the soil level, to impact zone (Arrêté de 25/01/91)

$$
\mathrm{R}=3600 \cdot \mathrm{V} \cdot \mathrm{A} \cdot \frac{273+\mathrm{t}}{273}\left[\frac{\mathrm{m}^{3}}{\mathrm{~h}}\right]
$$

$\Delta \mathrm{T}[\mathrm{K}]$ - difference between flue gases temperature at the outlet in chimney and the annual average air temperature from the site.

$$
\Delta \mathrm{T}=353,15-288,15=65[\mathrm{~K}]
$$

$\mathrm{t}$ - the flue gases temperature to the outlet chimney; $\mathrm{t}=80{ }^{\circ} \mathrm{C}$;

Maximum admissible concentrations for SOx, dust and NOx, according to Law no. 278/2013, Annex 6, of the 3 values calculated for $q$ choose the highest value to calculate $S$ and $H_{c}$ implicitly.

$$
\begin{aligned}
& \mathrm{q}=42117.9 \cdot 480 \cdot 10^{-6} \cdot \frac{273}{273+80}=15.63 \frac{\mathrm{kg}}{\mathrm{h}} \mathrm{NO}_{\mathrm{x}} \\
& \mathrm{H}_{\mathrm{c}}=30.82 \mathrm{~m}
\end{aligned}
$$

It is found that by this method, between the value of the chimney height obtained from the environmental agreement and the value of the chimney height in the sizing calculation results a difference of $0.82 \mathrm{~m}$. 


\section{INTERNATIONAL SYMPOSIUM "THE ENVIRONMENT AND THE INDUSTRY", SIMI 2018, PROCEEDINGS BOOK}

ORDONNANCE SUR LA PROTECTION DE L'AIR (R.S. 814.318.142.1, ANNEXE 6)

Method for determination the chimney height by Fig. 2 Nomogram starting from rate value $\mathrm{Q} / \mathrm{S}$ (Q expressed in $\mathrm{g} / \mathrm{h}$ and $\mathrm{S}$ expressed in $\mu \mathrm{g} / \mathrm{m}^{3}$ ) and the value of the $\mathrm{F}$ factor (ascendant flow) calculated with the relation (7):

$$
\mathrm{F}=3,18 \cdot 10^{-6} \cdot \mathrm{R}_{\mathrm{n}} \cdot \Delta \mathrm{t}=15.23
$$

where: $\quad R_{n}$ - volumetric flow rate of the flue gases in normal conditions, 68403

$\mathrm{Nm}^{3} / \mathrm{h}$ cu $11 \% \mathrm{O}_{2}$.

$$
\Delta \mathrm{t}=\mathrm{t}-10{ }^{\circ} \mathrm{C}=80-10=70{ }^{0} \mathrm{C}
$$

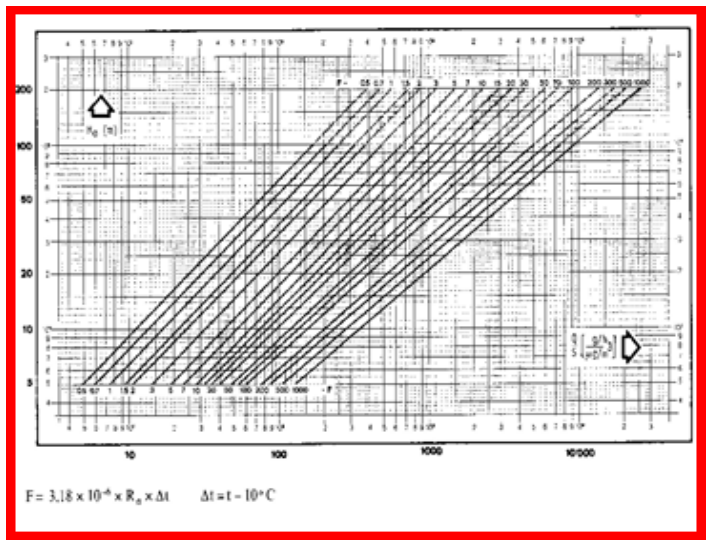

Figure 2. Nomogram for determination the chimney height of incinerator (R.S. 814.318.142.1, Annexe 6)

For $\mathrm{Q} / \mathrm{S}=210.13\left[\frac{\mathrm{g} / \mathrm{h}}{\mu \mathrm{g} / \mathrm{m}^{3}}\right]$, for $\mathrm{NO}_{2}$ and $\mathrm{F}=15.23$ from nomogram is obtained an initial value for chimney high, $\mathrm{H}_{0}=24 \mathrm{~m}$, which takes into account only the parameters of the transmitted emission. For value correction taking into account the weather parameters that can influence the dispersion of pollutants in the air and of the any obstacles due to the relief or buildings situated on the site the value $\mathrm{H}_{0}$ is a series of corrections as follows:

1. Wind intensity correction for interest site, the $f$ factor:

$$
\mathrm{H}_{1}=\mathrm{f} \cdot \mathrm{H}_{0}
$$

For $\mathrm{f}=1.25$, intermediate intensity wind, $\mathrm{H}_{1}=\mathrm{f} \cdot \mathrm{H}_{0} \Rightarrow \mathrm{H}_{1}=1.25 \cdot 24=30 \mathrm{~m}$.

$\mathrm{H}_{1}$ - the minimum height of the incinerator chimney placed on flat, unobstructed land.

2. High obstacles correction: buildings, vegetation placed near the incinerator by an overhang $\mathrm{I}_{1}$.

$$
\mathrm{H}_{2}=\mathrm{H}_{1}+\mathrm{I}_{1} \text {; }
$$

There are no high obstacles in the incinerator's area and for those conditions the correction will not be applied. 


\section{INTERNATIONAL SYMPOSIUM "THE ENVIRONMENT AND THE INDUSTRY", SIMI 2018, PROCEEDINGS BOOK}

\section{Conclusions}

According to the Air Technical Guidelines (TA Luft), the imissions assessment area caused by the incineration plant is the surface that is completely inside the circle around the chimney, which is 50 times the real height of the chimney and in which the additional pollution has more than $3.0 \%$ of the value of the long-term imissions concentration.

The actual height of the incinerator chimney is $30 \mathrm{~m}$. With the help of dispersion calculation, it is checked whether outside the scope of assessment there exists, for example, additional dust pollution for dust, $\mathrm{NO}_{2}$ and $\mathrm{SO}_{2}$.

As a result of calculations according to the "Arrêté du 25/01/91 relatif aux incinération de résidus urbains", between the value of the chimney in the environmental agreement and the value of the chimney height in the sizing calculation results a difference of $0,82 \mathrm{~m}$; it is specified that the average annual air temperature in the site area is an important factor in determining the height of the chimney, in determining the height of the flue and in calculating the dispersion of the pollutants; the average gas velocity entering the sizing calculation is a parameter chosen in the range of 8.0-12 m/ s, depending on other parameters.

The third methodology for verifying the height of the emission dispersion chimney results in the minimal height of the incinerator chimney located on flat, unobstructed land areas of $30 \mathrm{~m}$.

Through all three methodologies, the minimum chimney height, depending on the pollutant categories and their concentrations, is at least $30 \mathrm{~m}$, as is the actual height of the chimney height.

\section{References}

Arrêté de 25/01/91 relatif auxinstallation d'incinération de résidus urbains.https://aida.ineris.fr/consultation_document/5927. In French.

Directive 2000/76/EC of the European Parliament and of the Council on the incineration of waste. Available from: https://www.retim.ro/legislatie/Directiva_2000_76_CE.pdf.

Environmental agreement for the project "The installation for waste incineration", SC PRO AIR CLEAN SA. Available from: http://wwwold.anpm.ro/upload/39867_Acord\%20de\%20mediu\%20SC\%20PRO\%20AIR \%20CLEAN.pdf.

Integrated Pollution Prevention and Control, Reference Document on the Best Available Techniques for Waste Incineration. Available from: http://eippcb.jrc.ec.europa.eu/reference/BREF/wt bref 0806.pdf. [August 2006].

Lazaroiu, Gh, Patrascu, R \& Gheorghe, C 2005, Impact of CTE on the environment applications, Politehnica Press Publishing House, Bucharest, pp. 145.

Lazaroiu, G 2006, Dispersion of pollutants, Agir Publishing House, Bucharest, pp. 307.

Ordonnance sur la protection de l'air. Available from : https://www.admin.ch/ch/f/rs/8/814.318.142.1.fr.pdf;/R.S.814.318.142.1. In French.

Law no. 278/2013 regarding industrial emissions 


\section{INTERNATIONAL SYMPOSIUM "THE ENVIRONMENT AND THE INDUSTRY", \\ SIMI 2018, PROCEEDINGS BOOK}

Neue TA-LUFT. Available from:

http://m.bmu.de/fileadmin/Daten_BMU/Download_PDF/Luft/taluft_engl.pdf [24 July 2002]

Serbanescu, A, Barbu, ME, Nicolescu, IC \& Bucur, E 2017, 'Interdependence between total organic carbon content and heating value of sewage sludge samples', 20 $0^{\text {th }}$ International Symposium “The Environment and The Industry”, SIMI 2017, National Research and Development Institute for Industrial Ecology ECOIND, Bucharest, pp. 272-278.

Technical Normative about waste incineration from 26/11/2004 published in Official Monitor, parte I no.86 encore from 26/01/2005. 